\title{
Ahmad Khan \\ An Empire of Elites: Mobility in the Early Islamic Empire
}

\begin{abstract}
This study uses prosopographies pertaining to political elites from Khurāsān in order to examine patterns of social mobility, professional circulation, and structures of imperial rule in the 'Abbāsid Empire during the $8^{\text {th }}-9^{\text {th }}$ centuries. It suggests that the early 'Abbāsid Empire was dominated by informal patterns of rule that depended disproportionately on personal retainers and elite gubernatorial and military families to maintain structures of an otherwise bureaucratic centralized empire.
\end{abstract}

Keywords: Early Islamic Empire; elites; Khurāsān; 'Abbāsids; governors; mobility

\section{Introduction}

The early Islamic Empire exhibits one of the most ambitious attempts in late antique and medieval history to maintain structures of economic, political, and administrative control over territories ranging from North Africa to the Hindu Kush. The truly labyrinthine scale of this empire and its diverse communities raises the question of how to write the history of the early Islamic Empire and its provinces. One $10^{\text {th }}$-century observer of medieval Islamic politics and society has suggested one approach to this historiographical conundrum: ${ }^{1}$

\footnotetext{
Ahmad Khan, Assistant Professor, The American University in Cairo. This research was conducted under the auspices of the ERC project 'The Early Islamic Empire at Work-The View from the Regions Toward the Center' (Advanced Grant no. 340362). I should like to thank the two anonymous reviewers for their helpful comments on an earlier draft of this paper. I am grateful to Professor Jürgen Paul for reading and commenting on this paper with his usual rigor and analytical precision.
}

1 [Pseudo-] al-Māwardī, 1988, ed. Khaḍar Muḥammad Khaḍar, 186 = [Pseudo-] al-Māwardī, 1988, ed. Fu'ād 'Abd al-Mun'im Ahmmad, 239. On the false attribution of this text to al-Māwardī, see the pioneering contribution of Fu'ād 'Abd al-Mun'im Aḥmad, "Muqaddimat al-tahqīq wa-ldirāsa”, in Nașiḥat al-mulūk (1988), 5-33; Fu'ād 'Abd al-Mun'im Ahmad, Abū l-Ḥasan alMāwardī (n.d.). The most recent and comprehensive investigation belongs to Marlow 2016a. Marlow has published some of her findings elsewhere in publications going back some ten years: Marlow 2007, 181-92; Marlow 2016b, 35-64.

○ OpenAccess. () 2020 Ahmad Khan, published by De Gruyter. (cc) BY-NC-ND This work is licensed under the Creative Commons Attribution-NonCommercial-NoDerivatives 4.0 License. 
In the maintenance of the empire and its great provinces, it is impossible to dispense with viziers, deputies, secretaries, commanders of armies, overseers of military affairs, directors of police, overseers or leaders, officers of the guard, gatherers of information, financial agents, governors, and judges (lā budda fĩ iqāmat al-mamlaka wa-l-wilāyāt al-'azìma min

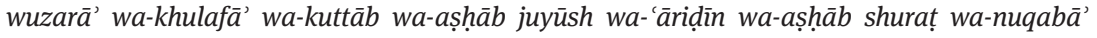
wa-aṣhāb ḥaras wa-aṣhāa akhbār wa-wulāt wa-quḍāt).

The unknown author of Counsel for Kings was convinced of the indispensable contribution elite officials made to the maintenance of the empire and its imperial provinces. The study of these elite officials is as good a place as any to begin an inquiry into elites in early Islamic societies and what impact they had on the organisation, administration, and management of the early Islamic Empire. ${ }^{2}$ This article uses a prosopographical approach to document and study social trends relating to the functions of elite officials in the $8^{\text {th }}$ and $9^{\text {th }}$ centuries. First, I document the mobility of elites across the various regions of the early Islamic Empire. Second, I highlight the circulation of elites within different offices and positions of authority, providing instances of social climbing among elite officials; that is to say, examples of elite officials who acquired higher offices. These social patterns are discernible based on a prosopographical analysis of the careers of state officials, and they bring into clearer focus the extent to which transregional mobility was a fundamental dimension of the early Islamic Empire's bureaucratic, military, and gubernatorial elite.

Prosopography of elites has long been recognised as a sine qua non of social histories of ancient and medieval empires. ${ }^{3}$ Since the beginning of the $20^{\text {th }}$ century, historians of ancient Rome have worked towards a prosopography of the empire. ${ }^{4}$ Theodor Mommsen began work on a prosopography of officials assuming secular and ecclesiastic offices as early as $1874 .{ }^{5} \mathrm{H}$. I. Marrou and A. H. M. Jones made great strides in advancing Mommsen's endeavour and by 1972 pub-

2 In a separate publication, I have studied the organisation of empire in one region of Khurāsān based on a prosopographical analysis of officials who appear in $8^{\text {th }}$-century documentary sources. See Khan (forthcoming), "The idea and practice of empire: the view from the documentary sources."

3 Olszaniec 2013; Tackett 2014; Preiser-Kapeller 2010. I would like to thank Johannes Preiser-Kapeller for discussing with me his combination of prosopographical methods and network analysis.

4 For a broad overview of prosopographical studies of the Roman Empire, see Cameron 2003; Barnes 2007, 83-94, 231-40.

5 In 1874, Mommsen submitted a hand-written proposal for a prosopography of the imperial period. This has been published by Eck 2003, 11-23. 
lished their landmark Prosopography of the Later Roman Empire. ${ }^{6}$ A decade later, Patricia Crone made an important case for early Islamic prosopographical studies in Slaves on Horses, her iconic study of medieval Islamic society, ${ }^{7}$ which purports to offer nothing less than an explanation for the form and structure of the medieval Islamic polity. The book continues to be remembered and debated because of its erudite (though controversial) historical assertions, delightful locutions, and analogical and comparative historical writing (a form in many ways unique to Crone's oeuvre). ${ }^{8}$ Still, the written prose sections of Slaves on Horses extend to only ninety pages. The remaining two hundred pages of the book constitute a vital prosopography of the early Islamic Empire and its imperial and provincial elites.

Slaves on Horses noticeably fails to integrate this valuable prosopographical data into the text, ${ }^{9}$ and there seems to be no attempt to interpret these details

6 Jones and Marrou 1951, 146 -7; Marrou 1951a, 26 -27; Marrou 1951b, 28-32; Jones and Martindale 1971-2.

7 Crone 1980, 16-17.

8 On this point, see Hillenbrand 1982, 116-9: "The style of the book is difficult and convoluted. Valuable and penetrating insights are often hidden behind a dense hedge of verbal pyrotechnics...In general, there is no steady exposition of a hypothesis, and only a minimum of background information. Instead, much of the book consists of staccato generalisations, couched in terms that brook no contradiction...Her weakness for the telling image permits such statements as the following: 'Nothing less than a restoration of Adam's faith in a post-physical world could now save the marriage between religion and power to which the Islamic polity owed its existence. And whether this polity could survive the divorce proceedings was still an open question' (p. 85). Dr Crone's style, moreover, makes a fetish of antithesis; this feature even pervades the footnotes. Note 649 is a typical example: "Merovingian fainéance meant Carolingian consolidation, just as 'Abbāsid fainéance was in due course to mean Seljuq unification." On the book's comparative historical method, "Another stylistic weakness of the book -indeed, one which becomes a weakness of method-is its frequent use of analogies from a wider sweep of history than any single scholar can be expected to control... Whilst it is no doubt worthwhile to avoid interpreting early Islamic history, or indeed any other kind of history, in a hermetically sealed way, analogies such as these-and many others too numerous to citewhich appear both in the text and the footnotes, and which cover such a wide geographical area and chronological time-scale, are at once facile and contrived. This is comparative historical analysis at its most superficial, and it distracts the reader from the main subject of the book." Similar objections to this method and style can be found in Donner 1982, 367-71. Wickham describes Crone's method as "analogical” in Wickham 1982, 106.

9 Consider the following observations: Wickham 1982, 105-7, 107: "Although Slaves on Horses seems long enough, at 300 pages, it is in reality rather short, and this in itself explains the dense and abbreviated nature of the writing: the main text is less than 90 pages, the remainder divided between appendices and notes...the appendices, all prosopographical...are useful, certainly, though surprisingly little-integrated into the text; yet it does not seem to me that they stand 
and records. ${ }^{10}$ This is all the more surprising in light of the emphatic case Crone makes for the value of prosopography to the study of early Islamic history. "Early Islamic history has to be almost exclusively prosopographical," she states in the introduction of Slaves on Horses. ${ }^{11}$ Nevertheless, the prosopographical data Crone furnishes represents a remarkable achievement, not least because of the painstaking and penetrating reading it demanded in an age when digital and searchable Arabic texts were not available to scholars. It is unfortunate that her superb prosopographical appendices have received little scholarly attention. ${ }^{12}$ In what follows, I build on the prosopographical research of scholars such as Crone, Amikam Elad, and Hugh Kennedy, and pursue a line of inquiry proposed by the author of Counsel for Kings to show how the early Islamic Empire was constituted of mobile and transregional elites.

\section{Mobility}

In governing such a vast landscape of imperial provinces one of the immediate problems that presented itself to the early Islamic Empire was connecting disparate and demographically diverse communities. The provinces of Iraq, Egypt, Fārs, Khurāsān, Shām, Ifrīqiya, and the Jazīra were shaped by very different social and political realities. Their communities belonged to different though not incongruent confessions, each with its own ecclesiastical organisations and in-

on their own, either, for they are confessedly incomplete, and an incomplete prosopography has much the same drawbacks as an incomplete dictionary. I leave it to Arabists, though, to determine whether these lists will be as useful as the book as a whole." In a similar vein, Hillenbrand 1982, 116-9 writes: "Perhaps the most impressive section of the book is the corpus of prosopographical information contained in the appendices (93-200)...Generally, however, the mass of information in the appendices is not integrated into the main sweep of the book's argument... in general her superbly documented appendices remain largely unexplained...instead of marshalling the majority of such evidence in the text itself and integrating it into the argument, Dr Crone has chosen to hide it away in the book's 711 footnotes or to assume that such facts are simply too well-known to require any explanation." See also Robinson 2015, 597-620, 606, fn. 44.

10 Crone 1980, 3, where Crone herself describes the work as "simply an overextended footnote." 11 Crone 1980, 17.

12 A critical work in the field of prosopographical studies in early Islamic history is Ahmed 2011. The title, perhaps too modestly, describes the work as a study of the religious elite. In fact, the book is an exceptionally detailed and lucid account of religious and political elites in early Islamic society. 
stitutions. ${ }^{13}$ Another layer of complexity was added by a dizzying variety of ethnicities and tribal identities in these provinces.

The $7^{\text {th }}$ century represented an experimental phase in the early Islamic Empire's attempts to establish some semblance of provincial authority. ${ }^{14}$ The case of Khurāsān points to the important role played by large-scale migration in the projection and practical implementation of imperial power. When the first Arab governors were appointed over the province of Khurāsān, they arrived in the province along with a substantial proportion of their tribal group. ${ }^{15}$ The logic guiding this kind of mass migration was simple and pragmatic. Governors from outside the province of Khurāsān belonged to a new cadre of transregional elites. They realised that establishing their authority in any one of the imperial provinces was no straightforward task. They depended therefore on the secure power base provided by members of their own tribe. As the Counsel for Kings reminds us, however, the makeup of the imperial elite was not limited to governors. Commanders of armies and overseers of military affairs (așhāb juyūsh wa-'āridīn) were perhaps the most mobile and transregional elite group.

\section{Elite Families: the Abū Ghānims ${ }^{16}$}

The imperial elite consisted of both a military and civilian elite. Both groups were integral insofar as they were willing to be deployed anywhere in government service. Flexibility was paramount.

The career of Abū Ghānim 'Abd al-Hamīd b. Rib'ī and that of his family exemplifies the transregional mobility demanded of military elites. ${ }^{17}$ Abū Ghānim first appears in the literary record as a propagandist of the 'Abbāsid revolution in

13 See Robinson 2000, 9-108; Payne 2015; Mikhail 2014; Tannous 2010, 379-569.

14 Hoyland 2015.

15 Al-Ṭabarī, Ta’rīkh (1879-1901), ii: 1291 = XXIV, 14; ii: 49-2 = XX: 72-74.

16 A genealogical table of this family is appended to this article.

17 My examination analyses the transregional mobility of this family in the provinces and regions of the early Islamic Empire. Modern prosopographical summaries or mentions of Abū Ghānim and some of his descendants can be found in: Crone 1980, 174-5; Elad 2013, 245-84, 270 -5; Kennedy 2001, 81 (Ḥumayd b. 'Abd al-Ḥamīd), 104 (Muḥammad b. Ḥumayd al-Ṭūsī), 120 (Ḥumayd b. 'Abd al-Ḥamīd), 123 (Ḥumayd b. 'Abd al-Ḥamīd), 124 (Ḥumayd b. 'Abd al-Ḥamīd); Kennedy 1981, 165 (Ḥumayd b. 'Abd al-Ḥamīd); Al-Janābī 1980, 221-45; Amabe 1995, 132-333; Agha 2003, 339. For Abū Ghānim in the medieval sources from the Damascene perspective, see Ibn 'Asākir, Ta'rīkh madīnat Dimashq (1996), 34: 66-67, who also quotes from Abū l-Ḥusayn al-Rāzì's (d. 347 H/958 CE) lost history of Damascus. With respect to this lost work, see Conrad 1991. 
Marv. ${ }^{18}$ He served as a general and chief of police (șāhib al-shurța) under his cousin Qaḥțaba b. Shabīb al-Ṭầ' 'Abbāsid revolution in Khurāsān. ${ }^{19}$ Abū Ghānim's role in Khurāsān seems to have come to an end with the death of Qahțaba b. Shabīb in $132 \mathrm{H} / 749 \mathrm{CE},{ }^{20}$ but he was sufficiently prominent enough to find himself in the assembly of al-Saffāh (r. 132-749 H/136-754 CE) during his initial coronation as caliph. ${ }^{21} \mathrm{~A}$ year later, he participated in the battle of the Zāb in Iraq. ${ }^{22}$ In the same year, he emerged in the province of Shām as one of the leading military commanders (quwwād) under 'Abdallāh b. 'Alī b. 'Abdallāh b. al-'Abbās. ${ }^{23}$ When 'Abdallāh b. 'Alī departed to attend to a rebellion in Qinnasrīn, he appointed Abū Ghānim as his deputy in Damascus. Abū Ghānim governed the city with four thousand troops, the majority of whom were Khurāsānī. ${ }^{24}$

Abū Ghānim's significance as a military leader can be gleaned from the fact that his involvement in the political life of two different provinces occurred during pivotal episodes in the history of these provinces: his service in Marv was on the eve of the 'Abbāsid revolution, whilst his role as 'Abdallāh b. 'Alī's deputy in Damascus came in the context of the latter's claim to be al-Saffāh's successor in opposition to al-Manșūr. ${ }^{25}$ Clearly, men of Abū Ghānim's military pedigree were in demand in more than one province, and they were called upon in the most precarious political situations.

Despite Abū Ghānim's residence in more than one of the empire's imperial provinces, he seems to have made Khurāsān his home before 'Abdallāh b. 'Alī's defeat forced him to flee to al-Ruhā', where he was discovered and dispatched to al-Manșūr. ${ }^{26}$ Once again, his reputation came to his rescue. Firstly, a close companion of Abū Ghānim was dispatched to al-Ruhāà to restore

18 Anonymous, Akhbār al-dawla al-'abbāsiyya (1971), 1: 217, 220.

19 On their kinship, see: Ibn al-Kalbī, Ğamharat an-nasab (1966), 257; Ibn Hazm, Jamharat ansāb al- 'arab (1962), 404. On Abū Ghānim’s military service under Qaḥțaba, see: al-Ṭabarī, Ta'rīkh (1879-1901), ii: 2001 = XXVII: 107-8 (as a military officer in Ṭūs); iii: 15 = XXVII: 137 (as Qaḥțaba’s șāhịib al-shurța).

20 Al-Ṭabarī, Ta'rīkh (1879-1901), iii: 11-19 = XXVII: 134-40 (Qaḥṭaba’s death); al-Ṣafadī, Umarā' (1983), 50, 72.

21 Al-Ṭabarī, Ta'rīkh (1879-1901), iii: 28 = XXVII: 151-2 and 36 = XXVII: 160.

22 Al-Ṭabarī, Ta'rīkh (1879-1901), iii: 38 = XXVII: 107-8.

23 Al-Ṭabarī, Ta’rīkh (1879-1901), iii: 53-54 = XXVII: 177-8.

24 Al-Ṭabarī, Ta'rīkh (1879-1901), iii: 53-54 = XXVII: 177-8; Ibn 'Asākir, Ta'rīkh madīnat Dimashq (1996), 38: 428; al-Ṣafadī, Umarā' (1983), 72.

25 Al-Ṭabarī, Ta’rīkh (1879 -1901), iii: 93 = XXVIII: 9; al-Ṣafadī, Umarā' (1983), 72; Ibn Kathīr, alBidāya (2010), 10: 277.

26 Al-Balādhurī, Ansāb (1978), 3: 109. 
order, a man who could be depended on to treat him respectfully despite the circumstances. Secondly, al-Manșūr overlooked his advocacy for the rival claimant to the caliphate. The caliph claimed that he could not bring himself to kill a member of the Qaḥtaba family and instead pardoned him. ${ }^{27}$ Some reports even suggest that he spent the rest of his life in exile on one of al-Manșūr's ancestral estates. $^{28}$

Abū Ghānim's two sons, Așram b. 'Abd al-Ḥamīd and Ḥumayd b. 'Abd alHamīd, were from Khurāsān. ${ }^{29}$ It is likely that Așram was the eldest. Like their father, they pursued military careers all over the empire. The Tārīkh-i Sīstān informs us of Așram's appointment as governor of Sīstān in the year 170 H/786 CE, after Hārūn al-Rashīd (r. 170 - 193 H/786-809 CE) appointed al-Faḍl b. Sulaymān as the super-governor of Khurāsān and Fārs. ${ }^{30}$ Al-Faḍl b. Sulaymān in turn installed Așram in Sīstān, ${ }^{31}$ where his gubernatorial reign was initially brief. It seems that he was appointed governor in 170 H/786 CE, removed, and then reappointed as governor a decade later. ${ }^{32}$ In this second period, he appointed his younger brother Humayd as one of his two deputy governors. ${ }^{33}$ When Aṣram died in Sīstān, ${ }^{34}$ Hārūn al-Rashīd promoted Humayd to governor in his brother's place. ${ }^{35}$

Ḥumayd resided in Khurāsān, where he cultivated a career as a military commander, but must have spent some considerable time in Sīstān deputising for and then replacing his older brother. ${ }^{36}$ When his term in Sīstān came to an end, he seems to have returned to Khurāsān, where he came to al-Ma'mūn's attention when al-Ma'mūn arrived in the province in 199-200 H/815-6 CE. In 201

27 Al-Balādhurī, Ansāb (1978), 3: 109-110.

28 Al-Balādhurī, Futūḥ (1878), 180.

29 Khalīfa b. Khayyāț, Ta'rīkh (1985), 463.

30 Anonymous, Tārīkh-i Sīstān (1935), 168 (caliph al-Hādī’s appointment of al-Faḍl b. Sulaymān as governor of Khurāsān), 169 (caliph Hārūn al-Rashīd's appointment of al-Faḍl b. Sulaymān as governor of Sīstān and Khurāsān (Hārūn al-Rashīd 'ahd-i Sīstān va Khurāsān suwī Fạ̣l b. Sulaymān farastād)). On al-Faḍl b. Sulaymān, see below ('II Circulation').

31 Anonymous, Tārīkh-i Sīstān (1935), 168 (va Fậl b. Sulaymān Așram b. 'Abd al-Ḥumayd [rā] Sìstān dād).

32 Anonymous, Tārīkh-i Sīstān (1935), 168 -9 (first appointment as governor), 172 (second appointment as governor).

33 Anonymous, Tārīkh-i Sīstān (1935), 168 (va Așram Ḥumayd b. 'Abd al-Ḥumayd rā barādar-i khwīsh rā bih khilāfat-i khwīsh bih Sīstān farastād). Așram's other deputy governor was Hamam b. Salama: Anonymous, Tārīkh-i Sīstān (1935), 172.

34 Khalīfa b. Khayyāț, Ta'rīkh (1985), 463; Anonymous, Tārīkh-i Sīstān (1935), 168 (a grave illness befell Așram b. 'Abd al-Ḥamīd (chūn Așram bih Sìstān āmad 'illatīi ș̣a'b ù rā pīsh āmad).

35 Anonymous, Tārīkh-i Sīstān (1935), 169, 172.

36 Anonymous, Tärīkh-i Sīstān (1935), 168. 
H/817 CE, al-Ma'mūn decided to send Humayd to Iraq to take charge of its khara $j,{ }^{37}$ and the rest of his career was in Baghdad.

Things began well. He received instructions directly from al-Ma'mūn during the latter's epochal journey from Khurāsān to Baghdād, ${ }^{38}$ and he was one of alHasan b. Sahl's (d. 203 H/819 CE) leading commanders. ${ }^{39}$ One can infer from the sources that he was a very effective one, ${ }^{40}$ and also a man not reluctant to express his dismay at the decisions of those he served. ${ }^{41}$ In the distressing circumstances of the fourth civil war, Humayd corresponded with 'İsā b. Muhammad Abī Khālid to secure the latter's surrender. ${ }^{42}$ Above all, he led the military efforts to diminish the authority of Ibrāhīm b. al-Mahdī. ${ }^{43}$ For these reasons, it is clear that he was integral to al-Ma'mūn's success in seeing off Ibrāhīm b. al-Mahdī's caliphal challenge. ${ }^{44}$

Humayd retained his position as chief commander when al-Ma'mūn arrived in Baghdad in $204 \mathrm{H} / 819 \mathrm{CE}$; he oversaw the army and the payment of salaries ${ }^{45}$ and was tasked with reorganising the military. ${ }^{46}$ He owned an estate (qașr) on the Tigris river. ${ }^{47}$ One $9^{\text {th }}$-century source describes him in $204 \mathrm{H} / 819 \mathrm{CE}$ as seated next to al-Ma'mūn during an intimate private banquet and as participating in the caliph's assembly (majlis). ${ }^{48}$ Al-Ma'mūn singled him out for praise on account of his practice of invocation (tasbih. $),{ }^{49}$ and the caliph was even aware of panegyrics

37 Al-Ya'qūbī, Kitāb al-Buldān (1860-1861), 306.

38 Ibn Abī Ṭāhir Ṭayfūr, Kitāb Baghdād (1949), 9.

39 Al-Ṭabarī, Ta'rīkh (1879-1901), iii: 1005 = XXXII: 51; Elad 2013, 245-84, 271.

40 Al-Ṭabarī, Ta'rīkh (1879-1901), iii: 1005-7 = XXXII: 51-54; 1018 = XXXII: 69; 1029 = XXXII: 82; 1034 = XXXII: 90; 1034 = XXXII: 90 -91; 1036 = XXXII: 92.

41 Al-Ṭabarī, Ta’rīkh (1879-1901), iii: 1019 = XXXII: 71.

42 Al-Ṭabarī, Ta'rīkh (1879-1901), iii: 1030 - 4 = XXXII: 86 - 89; al-Ya'qūbī, Ta’rīkh (1883), 2: 548.

43 Al-Ṭabarī, Ta'rīkh (1879-1901), iii: 1034-6 = XXXII: 89-92.

44 See also al-Ṭabarī, Ta'rīkh (1879-1901), iii: 1019 = XXXII: 71.

45 Ibn Abī Țāhir Ṭayfūr, Kitāb Baghdād (1949), 10.

46 Ibn Abī Ṭāhir Ṭayfūr, Kitāb Baghdād (1949), 4; al-Jāḥiz, Rasā’il (1964), ii: 206-8.

47 The purchase and fortification of an estate in the town of Qașr Ibn Hubayra by al-Tabarī, Ta'rīkh (1879-1901), iii: 1012 = XXXII: 60; al-Iṣfahānī, Kitāb al-Aghānī (1867), 28: 106; and for other estates, see al-Ṭabarī, Ta'rīkh (1879-1901), iii: 1018 = XXXII: 70. For a description of one of his fortresses, see al-Ișfahānī, Kitāb al-Aghānī (1867), 106. For more information concerning his wealth, see al-Ṭabarī, Ta'rīkh (1879-1901), iii: 1019 = XXXII: 71.

48 Ibn Abī Ṭāhir Ṭayfūr, Kitāb Baghdād (1949), 13, 16.

49 Ibn Abī Ṭāhir Ṭayfūr, Kitāb Baghdād (1949), 58-59: Ḥumayd was praised for the quality of his sacred incantations, Qaḥtaba for his prayers, Nūshjānī for his fasting, al-Marīsī for his ritual purification, Mālik b. Shāhī for building mosques, Ibrāhīm b. Barīha for his weeping at the pulpit, al-Ḥasan b. Quraysh for attending to orphans, Manjā for his story-telling, 'Alī b. Junayd for spending his wealth in the way of charity, Ishāa b. Ibrāhīm for hosting travelers, and so on. 
composed in Humayd's praise. Humayd is said to have been embarrassed by this fact and insisted on the pre-eminence of panegyrics composed in praise of the caliph. ${ }^{50}$

It appears, however, that something went terribly wrong. We only know of Humayd's rapid downfall because al-Jāhiz, always a contrarian, responded to a book praising officials with one condemning them. ${ }^{51}$ Al-Jāhìiz speaks of Humayd's suggestion to al-Ma'mūn that the army be reorganised to eliminate non-Khurāsānī elements and undeserving soldiers' salaries. ${ }^{52}$ Humayd shared the task with his secretary Mahmūd b. 'Abd al-Karīm. Together, they made a complete and unmitigated mess of it, and in the process Humayd's reputation was severely damaged. ${ }^{53}$ Al-Ma'mūn eventually intervened and took matters into his own hand..$^{54}$ Humayd's influence subsequently waned, ${ }^{55}$ and in $210 \mathrm{H} /$ 825-6 CE he was poisoned. ${ }^{56}$

Humayd's career was spent in the highest echelons of military and government service in the early Islamic Empire, from Khurāsān to Sīstān and from the empire's eastern provinces to its centre. He assumed a pivotal trust by supervising the collection of the kharāj. Humayd's loyalty to al-Ma'mūn and the stability of the empire's authority was also on display when he spearheaded the military and diplomatic efforts to quash Ibrāhīm b. al-Mahdī's precarious counter-caliphate. Humayd's trajectory is defined by the transregional mobility characteristic of his elite family and many others: a career that began and thrived in the empire's eastern provinces, only to end in ignominy in the empire's dynastic capital whilst dining with the caliph.

The career of Humayd's son Muhammad b. Humayd was scattered across the empire's regions and provinces. Ibn Abī Țāhir Ṭayfūr speaks of Muhammad b.

50 Al-Ṭabarī, Ta'rīkh (1879-1901), iii: 1153-4 = XXXII: 246-7. This was known to al-Ișfahānī, Kitāb al-Aghānī (1867), 18:100 - 8. Panegyrics extolling Ḥumayd were not an isolated occurrence. See al-Iṣfahānī, Kitāb al-Aghānī (1867), 3: 167 (describing the majesty of Ḥumayd's military retinue and his stature); 14: 36 - 37 (Humayd's confrontation with Țāhir prior to the latter's omission of the conventional invocation for the caliph al-Ma'mūn in the Friday sermon); 16: 163 (recited whilst passing by Hiumayd's grave and reflecting on the irony presented by Humayd's impressive resting place and his wrecked body); 18: 100-113 (panegyrics and H̦umayd's generous payment on hearing of them).

51 Al-Jāḥiz, Rasā’il (1964), 187.

52 Al-Jāhịiz, Rasā’il (1964), 206-7.

53 Al-Jāḥiż, Rasā’il (1964), 207-8 (al-Jāḥiz is explicit about Ḥumayd’s mismanagement).

54 Al-Jāḥiz, Rasā’il (1964), 208.

55 Al-Jāḥiz, Rasā’il (1964), 207-8.

56 Ibn Ḥabīb, Asmāà al-mughtalīn (1975), ii: 105-278, 199-200, where Ibn Ḥabīb sets the scene for Ḥumayd's poisoning. 
Humayd's appointment in Mecca in 210 H/826 CE to supervise its imām and the rites of pilgrimage. ${ }^{57}$ However, Muhammad b. Humayd was most active in Mosul, where the local historian al-Azdi describes his critical role in restoring order in $212 \mathrm{H} / 827-8 \mathrm{CE}$. Al-Ma'mūn was furious when he learned that the local governor of the Jazīra, al-Sayyid b. Anas al-Talīdī, had been killed whilst trying to suppress the rebellion of Zurayq b. 'Alī b. Șadaqa b. Dīnār al-Azdī. ${ }^{58}$ The caliph appointed Muhammad b. Humayd to lead the charge against Zurayq. ${ }^{59}$ His campaign was a success, and he delivered Zurayq to the caliph. ${ }^{60}$ The caliph in turn dispatched a victory letter to Muhammad b. Humayd in which he extolled him (and his father) and praised their loyalty and service. ${ }^{61}$ Al-Ma'mūn turned to Muhammad b. Humayd again in order to quell Bābak’s rebellion in Azerbaijan. ${ }^{62}$ This time, Muhammad b. Humayd was unsuccessful, and he was killed by Bābak's soldiers. ${ }^{63}$

The story of Abū Ghānim 'Abd al-Hamīd b. Rib'ī's important and well-travelled family did not end there. Abū Ghānim’s grandson Mahdī b. Așram followed his grandfather and father into a military career, suppressing revolts against the early Islamic Empire. 10 $0^{\text {th }}$-century cultural critics such as Abū Tammām (d. 335-6 H/946-7 CE) were well acquainted with the significance and memory of Abū Ghānim's family. Abū Tammām dedicated encomiums to Muhammad b. Humayd and another grandson of Abū Ghānim, Mahdī b. Așram; both were

57 Ibn Abī Ṭāhir Ṭayfūr, Kitāb Baghdād (1949), 116 (wajjaha Muhammad b. Ḥumayd al-Ṭūsī ilā Makka li-yaqifa ma' al-imām fì l-mawqif karāhat al-taḥallul fïhi, fa-tawajjaha ilā Makka wa-nafadha limā amara bihi wa-lam yakun shay' karihahu wa-raja'a bi-l-salāma). There are at least two possible philological interpretations for al-Ma'mūn's pretext for sending Muhammad to Mecca: that Muhammad was dispatched to supervise the imām of Mecca at the physical location where the restrictions of the state of ihrām end; or alternatively that concerns had been raised concerning the imām's handling of pilgrimage rites, Muhammad was sent to investigate, and he returned to Baghdad because he observed no such irregularities. Ibn Abī Țāhir Țayfūr, Kitāb Baghdād (1949), 117, informs us that Muhammad b. Humayd wrote to the governor of Mecca, Ṣāliḥ b. al-'Abbās b. Muhammad b. 'Alī b. 'Abdallāh b. 'Abbās, to give him the all clear to lead the official hajj procession in $210 \mathrm{H} / 826 \mathrm{CE}$.

58 Al-Azdī, Ta’rīkh al-Mawșil (1967), 372-81; Ibn al-Athīr, al-Kāmil (1987), 5: 484.

59 Al-Azdī, Ta’n̄ikh al-Mawșil (1967), 374, 378; Ibn al-Athīr, al-Kāmil (1987), 5: 484.

60 Al-Azdī, Ta'rīkh al-Mawșil (1967), 378-81; al-Ya'qūbī, Ta'rīkh (1889), 2: 564-5.

61 For the letter, its contents, and Muhammad's response to it, see al-Azdī, Ta'rīkh al-Mawșil (1967), 381-2.

62 Al-Azdī, Ta'rīkh al-Mawșil (1967), 378, 382-4; al-Ṭabarī, Ta'rīkh (1879-1901), iii: 1099-4 = XXXII: 176 - 7. See Crone 2012, 46-76, esp. 58 - 59 concerning the uprisings of Bābak and Zurayq. 63 While Ḥumayd was the subject of poetical encomiums, Muhammad b. Ḥumayd was rebuked severely by poets. We are told that (unlike his father) he was a miser and fled from battle. For a particularly scathing example, see al-Ișfahānī, Kitāb al-Aghānī (1867), 12: 104-5. 
killed whilst trying to put down Bābak's rebellion. ${ }^{64}$ There is an astonishingly singular thread running through these four generations of the Ghānim family: senior military commanders and governors from Khurāsān, operating in multiple regions of the empire, quelling revolts and uprisings against the caliph, and defending caliphal authority.

Ghānim b. Abī Muslim b. Humayd al-Ṭūsī, the great-grandson of Abū Ghānim and the grandson of Humayd, appears in the historical record outside the province of Khurāsān and in Mosul defending the territorial and political integrity of the early Islamic Empire and the caliph. In the year $231 \mathrm{H} / 846 \mathrm{CE}$, the persistent rebel Muhammad b. 'Amr al-Shaybānī initiated a small revolt in Diyār Rabī'a. ${ }^{65}$ Ghānim b. Abī Muslim was one of Mosul's most senior political figures, in charge of military affairs (wa-kāna 'ala harb al-Mawșil). ${ }^{66}$ Upon learning of Muhammad's uprising, Ghānim b. Abī Muslim and a small military entourage made their way to Diyār Rabī'a. They made very quick work of Muhammad b. 'Amr al-Shaybānī and his rebellion. While Muhammad b. 'Amr was taken captive and sent to Sāmarrā' before being transferred to Mațbaq prison in Baghdad, ${ }^{67}$ no such charity was shown to his fellow rebels. Their heads and banners were publically displayed at Khashabat Bābak: a truly macabre 'Abbāsid lieu de mémoire signifying the fate of those who rose against the empire.

Ghānim b. Abī Muslim's brother 'Abdallāh [b. Abī Muslim] b. Huumayd alṬūsī was not so fortunate. In $256 \mathrm{H} / 870 \mathrm{CE}$, the caliph al-Muwaffaq (r. 256$279 \mathrm{H} / 870-892 \mathrm{CE}$ ) was faced with the substantial uprising of the Zanj. Following the precedent of his ancestors, 'Abdallāh b. Abī Muslim b. Humayd was involved in attempts to subdue the rebels, and he and his son were both killed during a skirmish with the Zanj. ${ }^{68}$

The Ghānim family represents a broader pattern of (military) elite mobility in the early Islamic Empire. Khurāsān was the ancestral home of the Ghānims, but more importantly, in the late $8^{\text {th }}$ and $9^{\text {th }}$ centuries Khurāsān was at the very centre of the empire's production and training of military commanders and elites. ${ }^{69}$ It was from Khurāsān that the Ghānims established their presence in the empire's nearby and remote provinces and regions, making a name for themselves in Khurāsān; participating in battles in Iraq; quelling rebellions in Shām; assum-

64 Al-Ya'qūbī, Ta'rīkh (1883), 2: 565; Sezgin 1975, II: 583 and the sources cited therein.

65 For this episode, see al-Ṭabarī, Ta'rīkh (1879-1901), iii: 1351 = XXXIV: 367; al-Ya'qūbī, Ta'rīkh (1889), 2: 589; Ibn al-Athīr, al-Kāmil (1987), VI: 88.

66 Al-Ṭabarī, Ta'rīkh (1879-1901), iii: 1351 = XXXIV: 367.

67 Al-Ṭabarī, Ta’rīkh (1879-1901), iii: 1351 = XXXIV: 367; Le Strange 1900, 27; Lassner 1970, 243.

68 Al-Ṭabarī, Ta'rīkh (1879-1901), iii: 1837 = XXXVI: 110 -1.

69 De La Vaissière 2007. 
ing governorships in Sīstān; serving as Chief Commanders in the dynastic centre of the empire; and putting down major revolts in north-western Iran. The case of the Ghānims serves to show how mobility was essential not only to the interests of Khurāsānī elites, but also to the preservation of the early Islamic Empire's authority in all of its major provinces. The history, people, and elites of Khurāsān were implicated in the lives and fate of the entire empire.

\section{Circulation}

The study of the prosopography of elite officials reveals yet more important historical patterns concerning the contributions they made to the work of empire. The phenomenon of social climbing and the prospect of professional circulation within the vast imperial bureaucracy of the early Islamic Empire was reflected in the careers of a number of officials.

Such prospects were certainly brighter when one happened to be a scion of an illustrious family from Khurāsān and Transoxiana. In the case of al-Faḍl b. Sulaymān al-Ṭā'ì al-Ṭūsī, his paternal uncle was Abū l-'Abbās al-Ṭūsî, known for his active participation in a number of military skirmishes in Transoxiana during the caliphal reigns of Yazīd II and Hishām b. 'Abd al-Malik. ${ }^{70}$ On the eve of the 'Abbāsid revolution, al-Faḍl b. Sulaymān was busy instigating the 'Abbāsid revolution in Khurāsān and Transoxiana, and he was described as an 'Abbāsid propagandist operating out of Abīward. ${ }^{71} \mathrm{He}$ appears to have been a close confidante of Abū Muslim, who instructed him to move between the cities and villages of Khurāsān and Transoxiana in order to communicate messages on Abū Muslim's behalf. ${ }^{72}$

In $130 \mathrm{H} / 747-8 \mathrm{CE}$, al-Faḍl b. Sulaymān was in Ṭūs under the command of Qahțaba, where the former served alongside Abū Ghānim 'Abd al-Hamīd b. $\operatorname{Rib}^{1}{ }^{73}{ }^{73}$ A few years later, al-Faḍl b. Sulaymān was in Wāsiṭ with al-Ḥasan b.

70 Al-Ṭabarī, Ta'rīkh (1879-1901), ii: 1422 = XXIV: 152-3 (battle at the fortress of al-Bāhilī at Samarqand in the year $102 \mathrm{H} / 701-2 \mathrm{CE}$ ); ii: 1521-2 = XXV: 59 (siege of Kamarja in the year $110 \mathrm{H}$ / 728-9 CE).

71 Anonymous, Akhbār al-dawla (1971), 218, 221. His name appears alongside Abū Ghānim (again at 218) and 'Īsā b. Nahīk (at 218 with 'Uthmān b. Nahīk).

72 Al-Ṭabarī, Ta'rīkh (1879-1901), ii: 1950 = XXVII: 61-2, ii: 1963 = XXVII: 73, where the same story is repeated; Anonymous, Akhbār al-dawla (1971), 218-9.

73 Al-Ṭabarī, Ta’rīkh (1879-1901), ii: 2001 = XXVII: 107-8. 
Qaḥțaba, ${ }^{74}$ and it seems he found himself employed in Wāsiṭ again in the service of al-Manșūr during al-Saffāh’s reign. ${ }^{75}$

Upon the death of al-Faḍl b. Sulaymān's long-time compatriot 'Uthmān b. Nahīk, the position of caliph's guard passed on to the latter's son 'Īsā b. $\mathrm{Nahīk}^{76}$ and then to al-Faḍl b. Sulaymān (fa-ja'ala 'alā l-ḥaras Abā l-'Abbās alṬūsī). ${ }^{77}$ The precise year of al-Faḍl b. Sulaymān's appointment is unclear. First, the year of 'Uthmān b. Nahīk's death depends on the dating of the incident with the Rāwandiyya. ${ }^{78}$ Al-Ṭabarī believed this occurred in $141 \mathrm{H} / 758-9$ CE, though he is aware of reports that dated the event to $136-7 \mathrm{H} / 754-5 \mathrm{CE}^{79}$ Khalifa b. Khayyāt understood the employment history for the office of the caliph's guard and seal ('alā l-haras wa-l-khātam) to have progressed in this way from 'Uthmān b. Nahīk, to his son, and then to al-Faḍl b. Sulaymān. Khalīa b. Khayyāț, however, provides no date for al-Faḍl b. Sulaymān's appointment, and it is worth noting that he describes the two offices as having been passed on to al-Faḍl b. Sulaymān, whereas al-Ṭabarī speaks only of the position of the caliph's guard. ${ }^{80}$ To further complicate al-Faḍl b. Sulaymān's employment history we might add that al-Jahshiyārī (d. 331 H/942 CE) was of the view that al-Manșūr appointed al-Faḍl b. Sulaymān over the caliph's seal in 153 H/770 CE. ${ }^{81}$ Al-Faḍl b. Sulaymān replaced Muhammad b. Ibrāhīm as commander of al-Mahdi's haras. ${ }^{82} \mathrm{He}$ is described as being in charge of the private guard (alharas) in the reign of al-Mahdī, which then passed on to his son, 'Abdallāh b. Abī l-'Abbās al-Ṭūsī. ${ }^{83}$

In 146 H/763 - 4 CE al-Faḍl b. Sulaymān was ordered by the caliph al-Manșūr to track down Abū Zakariyyā' Yahyā b. 'Abdallāh. The latter was in charge of the accounts of Baghdad and its markets. It was discovered that he had a connection to the 'Alid rebels Muhammad al-Nafs al-Zakiyya and Ibrāhīm b. 'Abdallāh. AlFaḍl b. Sulaymān captured Abū Zakariyyā' and al-Faḍl b. Sulaymān's chamberlain, Mūsā, killed him (fa-qatalahu bi-yadihi hājiib kāna li-Abì l-'Abbās al-Ṭūsì). ${ }^{84}$

74 Al-Ṭabarī, Ta'rīkh (1879-1901), iii: 20-21 = XXVII: 142-3 (in the year 132 H/749-50 CE).

75 Al-Ṭabarī, Ta'rīkh (1879-1901), iii: 68 = XXVII: 191.

76 On 'Īsā, see Anonymous, Akhbār al-dawla (1971), 218; Omar 1969, 73; Crone 1982, 189.

77 Al-Ṭabarī, Ta'rīkh (1879-1901), iii: 131 = XXVIII: 64-66.

78 'Uthmān b. Nahīk and al-Faḍl b. Sulaymān served together in Ṭūs and Wāsiṭ. See al-Ṭabarī, Ta'rīkh (1879-1901), ii: 2001 = XXVII: 108 and iii: 68 = XXVII: 191.

79 Al-Ṭabarī, Ta'rīkh (1879-1901), iii: 129 = XXVIII: 62.

80 Khalīfa b. Khayyāț, Ta'rīkh (1985), 436.

81 Al-Jahshiyārī, Kitāb al-Wuzarā' (1980), 124 (qallada al-khātam al-Fạ̣l b. Sulaymān al-Ṭūsì).

82 Al-Ya'qūbī, Ta'rīkh (1883), ii: 483.

83 Khalīfa b. Khayyāț, Ta’rīkh (1985), 443.

84 Al-Ṭabarī, Ta'rīkh (1879-1901), iii: 324 = XXIX: 9. 
Al-Faḍl b. Sulaymān's chamberlain must have acquired quite a reputation for himself by this act, for he was thereafter tasked by al-Manșūr himself to execute certain individuals. ${ }^{85}$

There was no doubt that al-Faḍl b. Sulaymān was critical to the imperial household. In one source, he appears as al-Manșūr's close confidante, exhibiting no reluctance whatsoever to express himself to the caliph, even in cases where his was a voice of dissent concerning significant decisions involving the caliph's son and heir-apparent. ${ }^{86}$

\begin{abstract}
Al-Manșūr had gathered al-Faḍl b. Sulaymān, along with 'Īsā b. 'Alī, al-'Abbās b. Muḥammad, and others from among his select advisers (khawāsșihi) and told them: I have decided to assign the lands of the Sawād and Kuwar Dijla to al-Mahdì. All of the advisers present agreed with the caliph's judgment except al-Ṭūsī (fa-istașwaba jamī'uhum ra'yahu khalā lṬusì). Al-Ṭusi then requested the caliph whether he could speak with him privately (fa-innahu astakhlāhu). When they were alone, he said to the caliph: "Would it please you to know that al-Mahdī might pursue a policy different to yours and begin to run things carelessly?" "By God, no it would not please me," the caliph responded. "But, you would like to endear him to your subjects. The problem is that appointing him over these lands will make him loathed by your subjects, especially those among them who are loyal to you. Instead, you should appoint 'Īsā b. Mūsā as governor of this province and appoint al-Mahdī to oversee peoples' complaints. And you should command him to dispense justice to them in a fair manner.” Al-Manșūr began to laugh, and he stamped his feet on the ground [acknowledging al-Ṭūsī’s sagacious counsel].
\end{abstract}

Having served the caliph for many years in various provinces and in different imperial offices, al-Faḍl b. Sulaymān believed his relationship with al-Manșūr permitted such frank exchanges of policy. Delicate matters pertaining to the caliph's son and heir-apparent could be discussed between the two men. Based on this report, it might even be argued that al-Mahdī's interest in establishing courts of complaints (mazālim) originated with the idea al-Faḍl b. Sulaymān planted in alManșūr's mind. ${ }^{87}$

85 Al-Ṭabarī, Ta'rīkh (1879-1901), iii: 373 = XXIX: 68. From this source we learn that the name of al-Faḍl b. Sulaymān's chamberlain was Mūsā b. Dīnār. Kennedy in his translation cited above (XXIX: 68, fn. 181) remarks that Mūsā is "unknown elsewhere.” This is not correct.

86 Al-Jahshiyārī, Kitāb al-Wuzarā’ (1980), 37-38.

87 This report places the origins of the mazālim courts in a new light. To my knowledge, modern scholarship on the mazālim courts has overlooked this reference: Tyan 1938, 474; Tillier 2009, 42-6; Tillier 2006; Hallaq 2005, 99-101, and others place the origins of the mazālim courts with al-Mahdī, because of a dialogue preserved by Wakī' in which the qāḍ̄ 'Ubaydallāh speaks of being instructed by the caliph al-Mahdī to hear and investigate complaints: Wakī‘, Akhbār alquḍāt (1947-50), 2: 92. 
Circumstances continued to improve for al-Faḍl b. Sulaymān. Al-Manșūr's granting of properties to his senior commanders enabled al-Faḍl b. Sulaymān to amass a significant amount of property on the west side of Baghdad. ${ }^{88} \mathrm{Al}$ Faḍl b. Sulaymān in turn remained a loyal and dutiful officer. Upon al-Manșūr's death in $158 \mathrm{H} / 774-5 \mathrm{CE}$, in his capacity as keeper of the caliphal seal he had that seal sent to al-Mahdī (ba'atha Abū l-'Abbās al-Ṭūsì bi-khātam al-khilāfa). ${ }^{89}$ Even when all the imperial offices were placed under the ministerial control of Yahyyā b. Khālid during the caliphate of Hārūn al-Rashīd, the office of the caliphal seal maintained its independence under the authority of al-Faḍl b. Sulaymān (wa-kānat al-dawāwīn kulluhā ilā Yahyā b. Khālid ma' al-wizāra siwā dīwān alkhātam fa-innahu kāna ilā Abī l-'Abbās al-Ṭūsī). ${ }^{90}$ This was something that perturbed Yahyā b. Khālid, who was concerned over the delay in obtaining the caliphal seal from al-Faḍl b. Sulaymān for official letters. ${ }^{91}$

Provincial troubles in Khurāsān, however, signalled al-Fạ̣l b. Sulaymān's return to his home province of Khurāsān. Al-Mahdī had appointed Musayyab b. Zuhayr as governor of Khurāsān in 166 H/782-3 CE. Troubles for him began immediately on account of his decision to raise the land-tax above the amount at which it had been fixed..$^{92}$ Within eight months, Musayyab b. Zuhayr's gubernatorial reign was over and al-Mahdī replaced him with al-Faḍl b. Sulaymān. Gardīzì provides us with the precise details of the smooth transition of power: ${ }^{93}$

\begin{abstract}
Abū l-'Abbās sent out Sa'īd b. Bashīr as commander of the advance guard, and Sa'īd came to Marv in Muharram of the year 167 H/783 CE. He went into Musayyab's presence, greeted him, and gave him a letter instructing him to hand over his charge to Sa'îd. Musayyab had had no prior knowledge of this change of appointment. When Musayyab had read it, he rose from his place and said, "The seat of authority is now yours" (va Sa id bi Marv āmad...va bi nazdīk-i Musayyab shud va Musayyab hīch khabar nadāsht, va bar vay salām kard va nāmi-yi taslīm-i 'amal badū dād. Va chūn bi khwānd az jay-i khwīsh bar khāst va guft, "majlis turā ast”).
\end{abstract}

The man whose career began as an agent and messenger of Abū Muslim, scurrying between the cities and villages of Khurāsān and Transoxiana to convey messages on his behalf, returned to the province as its governor, an office that in-

88 Al-Ṭabarī, Ta'rīkh (1879-1901), iii: 367 = XXIX: 59.

89 Al-Ṭabarī, Ta'rīkh (1879-1901), iii: 455 = XXIX: 165.

90 Al-Jahshiyārī, Kitāb al-Wuzarā' (1980), 177.

91 Al-Jahshiyārī, Kitāb al-Wuzarā' (1980), 178.

92 Gardīzī, Zayn al-akhbār (1968), 282-3.

93 Gardīzī, Zayn al-akhbār (1968), 283. For this article, I have used 'Abd al-Ḥayy Habībī's edition and not Rahịm Riḍā-zāda Malik’s more recent edition (Tehran: Anjuman-i Āthār va Mafākhir-i Farhangī, 2005). 
cluded the regions of Sīstān and Ṭabaristān. ${ }^{94}$ His impact was felt across the empire's provinces and at the imperial centre, where there was even a quarter belonging to al-Faḍl b. Sulaymān. ${ }^{95}$

It is notoriously difficult to pursue the career of provincial governors beyond their gubernatorial reign. Upon being dismissed from their position, provincial governors often disappear into oblivion. In this respect, al-Faḍl b. Sulaymān is an important exception. His dismissal as governor of Khurāsān and Sīstān in 171 H/787-9 CE by the caliph Hārūn al-Rashīd was apparently not prompted by improper conduct or any incompetence in his handling of provincial affairs. That he was still trusted and honoured was shown on his arrival in Baghdad in $171 \mathrm{H} / 787-8 \mathrm{CE}$, when he was given charge of the caliphal seal. ${ }^{96}$

\section{Conclusion}

The aim of this study has been to deploy prosopography in order to document historical patterns and trends concerning the activities of elites in the early Islamic Empire. I have used this methodology to document the lives of elites who occupied leading positions in $8^{\text {th }}$ and $9^{\text {th }}$-century government in order to

94 Al-Ṭabarī, Ta'rīkh (1879-1901), iii: 517-8, 521 = XXIX: 234-5, 239; iii: 740 = XXX: 305; Ibn Isfandiyār, Tārīkh-i Ṭabaristān (1941), 1: 189. Abū l-'Abbās al-Ṭūsī is described as one of the governors of Țabaristān sent from Baghdad (dār al-khilāfa). It is unclear to me whether this appointment occurred earlier or whether Țabaristān was included under his autonomy along with Khurāsān and Sīstān. When al-Dīnawarī states that al-Faḍl b. Sulaymān remained governor for two years ("wa-'aqada li-Abī l-'Abbās al-Ṭūsì 'alā Khurāsān fa-labitha 'alayhā 'āmmayn thumma 'azalahu”), he must intend by this two years into Hārūn al-Rashīd's caliphal reign. I am reading 'aqada instead of the passive, 'uqida, on account of the entire sentence's syntax: al-Dinawarī, Akhbār al-țiwāl (1888), 383. For his and, subsequently, his son's governorship, see Ḥamza Ișfahānī, Ta'rīkh sin̄̄ mulūk (1844-1888), 222-3; al-Ṭabarī, Ta’rīkh (1879-1901), iii: 521 = XXIX: 239; Khalîfa states that Abū l-'Abbās al-Ṭūsī’s gubernatorial reign continued under the caliph al-Hādī: Khalīfa b. Khayyāt, Ta’rīkh (1985), 446; al-Fasawī states that he was governor of Khurāsān from 166-170 H/783-4-787-8 CE: al-Fasawī, Kitāb al-Ma'rifa (1989), i: 154, 162 (where the end of his gubernatorial reign is noted). For a full historical reconstruction and comprehensive discussion of his governorship, see Khan (forthcoming monograph), ch. 3 ('Governing the Empire').

95 Al-Ṭabarī, Ta'rīkh (1879-1901), iii: 274-5 = XXVIII: 242 (al-murabba'a al-ma'rūfa bi-Abì l'Abbās al-Fậll b. Sulaymān al-Ṭūsī). See Lassner 1970, 67.

96 See Khalīfa b. Khayyāț, Ta'rīkh (1985), 465: Abū l-'Abbās was in charge of the seal after Ja'far b. Muhammad b. al-Ash'ath. When the latter replaced Abū l-'Abbās as governor of Khurāsān, Abū l-'Abbās commanded the seal (al-khātam). He kept this office until he died and was replaced by Yaḥyā b. Khālid b. Barmak. 
point out larger themes and developments they represent. Prosopography promises to illuminate the study of early and medieval Islamic history when it addresses larger conceptual and thematic questions.

This study has been devoted to two neglected areas in the study of the early Islamic Empire and the role of elites towards the empire's stability. It has argued that transregional mobility, especially among military commanders, was foundational to the empire's maintenance. The elites studied in this chapter were active all over the empire's regions: from Mosul to Baghdad, from Khurāsān to Sīstān, from Ṭabaristān to Ṭūs, from Azerbaijan to Baghdad. The circulation of elites reflects the extent to which the fate of the empire was tied to elite activity. Offices and appointments circulated among family members, going from brother to brother, father to son; and officials were ambitious and enterprising, not always content with the offices and level of employment they or their ancestors had secured. Many of them were social climbers, who began their careers as soldiers, progressed to the caliph's special military entourage, and rose to prominence as governors of provinces. There were great opportunities to rise in the imperial bureaucracy but even the highest offices were not without their risks. When loyalty was rewarded, it was rewarded generously. But when it was breached, the consequences were grave and delivered swiftly. Heads could rise one day and fall quite literally the next, only to be raised and displayed with the hallmark, macabre display of imperial triumph in the empire's capital.

This mobility and circulation points to two further dimensions of the early Islamic Empire. The first was the cultural commensurability of the imperial provinces. Subjects and administrators floated across different regions of the empire. Cultures and customs differed, but the vast territorial diversity of the empire's landscape did not prevent a high degree of inter-cultural traffic. The second and perhaps more important dimension was the early Islamic Empire's creation of a commensurate system. A trans-empire identity made it possible for elites to move easily from province to province and swiftly embed themselves in a bureaucratic system where there were similar expectations; social roles were understood; positions of power were known; privilege and education were expected and recognised; and achievements in different provinces were accorded respect. ${ }^{97}$ This cultivation of a commensurable social world that enabled elite of-

97 On this point, see Ando (2000), 410, who states about the early Roman Empire: "It does not matter that most provincials probably never left the province in which they were born. Rather, their appreciation of the empire grew from the belief they shared with Orosius, that they could travel the length of the empire and still know precisely what benefits accrued from their membership in the Roman community." 
ficials to thrive whilst serving the interests of the early Islamic Empire was a significant achievement. ${ }^{98}$

Beyond these two hypotheses concerning the nature of the early Islamic Empire as an empire of mobile elites, this study has also advanced a less explicit, though obvious, argument about the history of Khurāsān and its relationship to the early Islamic Empire at large in the $8^{\text {th }}$ and $9^{\text {th }}$ centuries. Khurāsān was a major province of the empire. In a forthcoming monograph, I study the ways in which officials from Khurāsān were instrumental in supervising the affairs of small villages and towns within the province, ${ }^{99}$ as well as managing and directing the affairs of other provinces such as Egypt and Iraq. ${ }^{100}$ The present study has highlighted the kinds of interventions and contributions that Khurāsān's people and resources made in the lives of other regions of the empire. The impact its residents had outside Khurāsān was both spectacular and highly consequential. The sources do not detail the motivations or rewards for imperial service. What they do allow us to deduce is how fundamental elite activity of this kind was for the stability and maintenance of the early Islamic Empire. It could not have survived for as long as it did without reproducing generations of elites, from Khurāsān in particular, to do the work of empire in the province of Khurāsān, in the empire's other key provinces, and in the imperial centre.

Elites from Khurāsān can be found all over the early Islamic empire. This study has identified precisely where some of them were and what they were doing. It has presented a picture of the early 'Abbāsid Empire as one dominated by informal patterns of rule that depended disproportionately on personal retainers and elite gubernatorial and military families to maintain structures of an otherwise bureaucratic centralised empire. Only on the basis of a larger pool of prosopographies can we determine whether this pattern of rule characterises the nature of the early Islamic Empire more broadly.

98 Haldon 2016, 159-92. Charles Tilly's landmark study of mobility in early modern Europe has generated new typologies of mobility in medieval societies. Unfortunately, historians of early Islamic history have a long way to go before we can propose stable typologies of this kind. For some sense of what has been achieved by historians of the early Roman Empire, see the edited volume Migration and Mobility in the Early Roman Empire (2016).

99 See Khan (forthcoming journal article), "The Idea and Practice of Empire: the View from the Documentary Sources.”

100 Khan (forthcoming monograph), The Idea and Practice of Empire in Early Islamic Society. 


\section{Appendix}

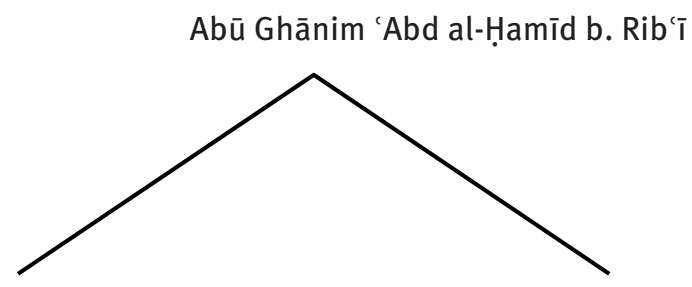

Așram b. 'Abd al-Ḥamīd

Ḥumayd b. 'Abd al-Ḥamīd

$$
\mid
$$

Mahdī b. Așram

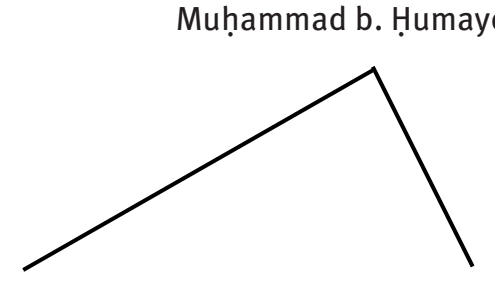

Ghānim b. Abī Muslim
'Abdallāh b. Abī Muslim

Genealogical table of Abū Ghānim and his descendants

\section{Bibliography}

\section{Primary sources}

Anonymous (1971), Akhbār al-dawla al-'abbāsiyya, edited by 'Abd al-'Azīz al-Dūrī, Beirut: Dār al-țalī'a li-l-țibā'a wa-l-nashr.

Anonymous (1935), Tārīkh-i Sīstān, edited by Muḥammad Taqī Bihār, Tehran: Mu'īn.

al-Azdī (1967), Ta'rīkh al-Mawṣil, edited by 'Alī Ḥabība, Cairo: Lajnat al-iḥyā' al-turāth al-'arabī.

al-Balādhurī (1978), Ansāb al-ashrāf, edited by 'Abd al-'Azīz al-Dūrī, Beirut and Wiesbaden:

Franz Steiner Verlag.

al-Balādhurī (1978), Kitab Futūḥ al-buldān, edited by M. J. de Goeje, Leiden: E. J. Brill.

al-Dīnawarī (1888), Kitāb al-Akhbār al-țiwāl, edited by Ignace Kratchkovsky, Leiden: E. J. Brill. 
al-Fasawī (1989), Kitāb al-Ma'rifa wa-l-ta'rīkh, edited by Akram Ḍiyā' al-'Umarī, Medina: Maktabat al-dār.

Gardīzī (1968), Zayn al-akhbār, edited by 'Abd al-Ḥayy Ḥabībī, Tehran: Intishārāt-i bunyād-i farhang-i İrān.

Ibn al-Athīr (1987), al-Kāmil fĩ l-ta'rīkh, edited by Muhạmmad Yūsuf al-Daqqāq, Beirut: Dār al-kutub al-ilmiyya.

Ibn 'Asākir (1996), Ta'rīkh madīnat Dimashq, edited by Muḥibb al-Dīn al-'Amrawī, Beirut: Dār al-fikr.

Ibn Ḥabīb (1975), 'Asmā’ al-mughtalīn min al-ashrāf fī l-jāhiliyya wa-l-Islām wa-asmā’ man qutila min al-shu'arā’', in Nawādir al-makhțūṭāt, Cairo: Mușțafā al-Bābī al-Ḥalabī.

Ibn Ḥazm (1962), Jamharat ansāb al-'arab, edited by 'Abd al-Salām Muḥammad Hārūn, Cairo: Dār al-ma'ārif.

Ibn Isfandiyār (1941), Tārīkh-i Tabaristān, edited by 'Abbās Iqbāl, Tehran: Majlis.

Ibn al-Kalbī (1966), Ǧamharat an-nasab, das genealogische Werk des Hišām b. Muhammad al-Kalbi, edited by W. Caskel and G. Strenziok, Leiden: E. J. Brill.

Ibn Kathīr (2010), al-Bidāya wa-l-nihāya, edited by 'Abd al-Qādir al-Arnā'ūṭ and Bashshār

'Awwād Ma'rūf, Beirut: Dār Ibn Kathīr.

al-Ișfahānī (1867), Kitāb al-Aghānī, Cairo: Būlāq.

Ḥamza al-Ișfahānī (1844), Ta'rīkh sinī mulūk al-arḍ wa-l-anbiyā', edited by J. M. E. Gottwaldt, Leipzig: Leopold Voss.

al-Jāḥiẓ (1964), 'Dhamm akhlāq al-kuttāb', in Rasā'il al-Jāḥiẓ, edited by 'Abd al-Salām Muḥammad Hārūn, Cairo: Maktabat al-khānjī.

al-Jahshiyārī (1980), Kitāb al-wuzarā' wa-l-kuttāb, edited by Mușțafā al-Saqqā, Cairo: Mușțafā al-Bābī al-Ḥalabī.

Khalīfa b. Khayyāṭ (1985), Ta'rīkh, edited by Akram Ḍiyā' al-'Umarī, Riyadh: Dār al-țayba.

[Pseudo-] al-Māwardī (1988), Nașịhat al-mulūk, edited by Khaḍar Muḥammad Khaḍar, Cairo: Maktabat al-falāḥ.

[Pseudo-] al-Māwardī (1988), Nașīhat al-mulūk al-mansūb ilā Abī l-Hasan al-Māwardī, edited by Fu'ād 'Abd al-Mun'im Aḥmad, Alexandria: Mu'assasat shabāb al-jāmi'a.

al-Ṣafadī (1983), Umarā’ Dimashq fĩ l-Islām, edited by Șalāḥ al-Dīn al-Munajjid, Beirut: Dār al-kutub al-jadīd.

al-Tabarī (1879-1901), Ta'rīkh al-rusul wa-l-mulūk, edited by M. J. De Goeje et al., Leiden: E. J. Brill.

Ibn Abī Ṭāhir Ṭayfūr (1949), Kitāb Baghdād, edited by Muhammad Zāhid al-Kawtharī, Cairo: Maktabat al-khānjī.

Wakī' (1947-50), Akhbār al-qựāt, edited by 'Abd al-'Azīz Mușțafā al-Marāghī, Cairo: Mațba'at al-sa'āda.

al-Ya'qūbī (1883), Ta'rīkh, edited by M. Th. Houtsma, Leiden: E. J. Brill.

al-Ya'qūbī (1860-1861), Kitāb al-Buldān, edited by A. W. T. Juynboll, Leiden: E. J. Brill.

\section{Studies}

Agha, Salih Said (2003), The Revolution which Toppled the Umayyads: Neither Arab nor 'Abbāsid, Leiden: Brill. 
Ahmed, Asad Q. (2011), The Religious Elite of the Early Islamic Hijaz: Five Prosopographical Case Studies, Oxford: Unit for Prosopographical Research.

Ando, Clifford (2000), Imperial Ideology and Provincial Loyalty in the Roman Empire, Berkeley: University of California Press.

Amabe, Fukuzo (1995), The Emergence of the 'Abbāsid Autocracy: the 'Abbāsid Army, Khurāsān and Adharbayjān, Kyoto: Kyoto University Press.

Barnes, T. D. (2007), "Prosopography and Roman History", and Marietta Horster, "The Prosopographia Imperii Romani (PIR) and New Trends and Projects in Roman Prosopography," in: K. S. B. Keats-Rohan, ed., Prosopography: Approaches and Applications. A Handbook, Oxford: Prosopographica et Genealogica, 83-94, 231-40.

Cameron, Averil, ed., (2003), Fifty Years of Prosopography: The Later Roman Empire, Byzantium and Beyond. Proceedings of the British Academy 118, Oxford: Oxford University Press.

Conrad, Gerhard (1991), Abū'l-Husain al-Rāzī (-347/958) und seine Schriften. Untersuchungen zur frühen damaszener Geschichtsschreibung, Stuttgart: Franz Steiner Verlag.

Crone, Patricia (2012), The Nativist Prophets of Early Islamic Iran: Rural Revolt and Local Zoroastrianism, Cambridge: Cambridge University Press.

Crone, Patricia (1980), Slaves on Horses: The Evolution of the Islamic Polity, Cambridge: Cambridge University Press.

Donner, Fred (1982), "Review of P. Crone, Slaves on Horses: The Evolution of the Islamic Polity, Cambridge: Cambridge University Press”, Journal of the American Oriental Society 102/2: 367-71.

Eck, Werner (2003), “The Prosopographia Imperii Romani and Prosopographical Method”, in: Averil Cameron, ed., Fifty Years of Prosopography: The Later Roman Empire, Byzantium and Beyond. Proceedings of the British Academy 118, Oxford: Oxford University Press, 11-23.

Elad, Amikam (2013), “Al-Ma'mūn's Military Units and Their Commanders up to the End of the Siege of Baghdad (195/810-198/813)", in: Monique Bernards, ed., 'Abbāsid Studies IV: Occasional Papers of the School of 'Abbāsid Studies Leuven, July 5-July 9, 2010, Exeter: Gibb Memorial Trust, 245-84.

Haldon, John (2016), The Empire That Would Not Die: The Paradox of Eastern Roman Survival, 640-740, Cambridge, Massachusetts: Harvard University Press.

Hallaq, Wael (2005), The Origins and Evolution of Islamic Law, Cambridge: Cambridge University Press.

Hillenbrand, Carole (1982), "Review of P. Crone, Slaves on Horses: The Evolution of the Islamic Polity (Cambridge: Cambridge University Press, 1980)”, Journal of Semitic Studies 27/1: $116-9$.

Hoyland, Robert (2015), In God's Path: The Arab Conquests and the Creation of an Islamic Empire, Oxford: Oxford University Press.

al-Janābī, Aḥmad Nașîf (1980), “Ḥumayd al-Ṭā'ĩ: a'ẓam quwwād al-Ma’mūn”, Majallat al-Majma' al-'Ilmī l-'Irāqī 31: 221-45.

Jones, A. H. M. / Marrou, H. I. (1951), "Deux projets de prosopographie concernant le Bas-Empire”, Actes du premier Congrès de la Fédération Internationale des Associations d'Études Classiques, Paris: C. Klincksieck, 146-7.

Jones, A. H. M. / Martindale, J. R. (1971-2), Prosopography of the Later Roman Empire (260-641), 2 vols., Cambridge: Cambridge University Press. 
Kennedy, Hugh (2001), The Armies of the Caliphs: Military and Society in the Early Islamic State, Oxford: Taylor and Francis, Routledge.

Kennedy, Hugh (1981), The Early Abbasid Caliphate: A Political History, London: Croom Helm. Khan, Ahmad (forthcoming), "The Idea and Practice of Empire: the View from the Documentary Sources", journal article.

Khan, Ahmad (forthcoming), The Idea and Practice of Empire in Early Islamic Society, monograph.

Lassner, Jacob (1970), The Topography of Baghdad in the Early Middle Ages, Detroit: Wayne State University Press.

De Ligt, Luuk / Tacoma, Laurens E., eds., (2016), Migration and Mobility in the Early Roman Empire, Leiden: Brill.

Marlow, Louise (2016a), Wisdom and Politics in Tenth-Century Iran, Vol. I: The Nașīhat al-Mulūk of Pseudo-Māwardī: Contexts and Themes; Vol. II: The Nașịhat al-Mulūk of Psuedo-Māwardī: Texts, Sources and Authorities, Edinburgh: Edinburgh University Press.

Marlow, Louise (2016b), "Abū Zayd al-Balkhī and the Nașīhat al-mulūk of Pseudo-Māwardī”, Der Islam 93: 35-64.

Marlow, Louise (2007), “A Samanid Work of Counsel and Commentary: The Nașịhat al-Mulūk of Pseudo-Māwardi”, Iran 45: 181-92.

Marrou, H. (1951a), "Notice on the Christian Prosopography of the Later Roman Empire", Folia 5: $26-27$.

Marrou, H. (1951b), “Christian Prosopography of the Later Roman Empire: Instructions for the Collaborators", Folia 5: 28-32.

Mikhail, Maged S. A. (2014), From Byzantine to Islamic Egypt: Religion, Identity and Politics after the Arab Conquest, London: I. B. Tauris.

Olszaniec, Szymon (2013), Prosopographical Studies on the Court Elite in the Roman Empire $\left(4^{\text {th }}\right.$ Century $\left.A D\right)$, translated by Kacek Welniak and Malgorzata Stachowska-Welniak, Toruñ: Nicolaus Copernicus University Press.

Omar, Farouk (1969), The 'Abbāsid Caliphate, Baghdad: National Printing and Publishing Co.

Payne, Richard E. (2015), A State of Mixture: Christians, Zoroastrians, and Iranian Political Culture in Late Antiquity, California: University of California Press.

Preiser-Kapeller, Johannes (2010), "Calculating Byzantium? Social Network Analysis and Complexity Sciences as Tools for the Exploration of Medieval Social Dynamics”, Working Paper.

Robinson, Chase (2015), “Crone and the End of Orientalism," in: Behnam Sadeghi et al., eds., Islamic Cultures, Islamic Contexts: Essays in Honor of Professor Patricia Crone, Leiden: Brill, 597-620.

Robinson, Chase F. (2000), Empire and Elites after the Muslim Conquest: The Transformation of Northern Mesopotamia, Cambridge: Cambridge University Press.

Sezgin, Fuat (1975), Geschichte des arabischen Schrifttums, Band II: Poesie, Leiden: Brill.

Le Strange, Guy (1900), Baghdad during the 'Abbāsid Caliphate from Contemporary Arabic and Persian Sources, Oxford: Clarendon Press.

Tackett, Nicolas (2014), The Destruction of the Medieval Chinese Aristocracy, Cambridge, Massachusetts: Harvard University Press.

Tannous, Jack B. V. (2010), Syria between Byzantium and Islam: Making Incommensurables Speak, PhD dissertation, Princeton University. 
Tillier, Mathieu (2006), “Un traité politique du Ile/VIlle siècle: l'épître de 'Ubayd Allāh b. al-Ḥasan al- 'Anbarī au calife al-Mahdī, Annales Islamologiques 40: 139-70.

Tillier, Mathieu (2009), "Qāḍīs and the Political Use of the maẓālim Jurisdiction under the 'Abbāsids”, in: Christian Lange and Maribel Fierro, eds., Public Violence in Islamic Societies: Power, Discipline, and the Construction of the Public Sphere, $7^{\text {th }}-19^{\text {th }}$ Centuries CE, Edinburgh: Edinburgh University Press, 42-66.

Tyan, Emile (1938), Histoire de l'organisation judiciaire en pays d'Islam, Paris: Annales de l'Université de Lyon.

Wickham, Chris (1982), "Review of P. Crone, Slaves on Horses: The Evolution of the Islamic Polity (Cambridge: Cambridge University Press, 1980)”, International Journal of Middle East Studies 14/1: $105-7$.

de la Vaissière, Étienne (2007), Samarcande et Samarra: Élites d'Asie centrale dans l'empire Abbaside, Paris: Studia Iranica. 
